\title{
What kind of Christianity? A v Switzerland
}

\author{
Deborah Thebault ${ }^{1}$ and Lena Rose ${ }^{2}$
}

\section{Introduction}

This comment explores how legal authorities understand religious identity and sets these understandings in a wider context. The comment questions whether the interpretation of the claimant's conversion to Christianity by the European Court of Human Rights and the Swiss Asylum authorities might not be too restricted to a particular Western European form of Christianity. The European Convention on Human Rights gives to the contracting States a certain margin of appreciation in assessing the risk of ill treatment undergone by a convert. In this case in its application of the Convention the ECtHR accepted the ruling of the Swiss authorities.

\section{The case}

A claimant from Iran came to Switzerland and underwent two sets of asylum proceedings. On his first application for asylum in 2009, the applicant stated that he entered Switzerland illegally after multiple events happened that would have allegedly led him to detention and illtreatment had he remained in Iran. The Swiss Asylum authorities rejected his first application based on contradictions regarding his insufficiently substantiated allegations, which seemed to lack credibility. On his second application for asylum in 2013, the applicant stated that he entered Switzerland legally based on a visa to visit his sister who lived there. He also related his conversion from Islam to Christianity on 25 August 2013 and argued that in case of return, he would expose himself to a real risk of being killed for apostasy or ill-treated on account of his conversion. The Swiss Asylum authorities and the Federal Administrative Court both dismissed his application. After these two rejections based on asylum proceedings, the claimant asked for temporary admission under section 83 of the Aliens Act of 16 December 2005, particularly based on his conversion and his active membership of a Christian community. The Swiss authorities rejected his application once again, as did the Federal Administrative Court, which ordered his deportation back to Iran. The question raised by the claimant before the European Court of Human Rights was whether his deportation to Iran would be in breach of Articles 2 (the right to life) and 3 (the right to freedom from inhuman and degrading treatment) of the European Convention on Human Rights owing to his conversion from Islam to Christianity.

\section{What kind of Christianity are we talking about?}

The Swiss authorities, affirmed by the ECtHR applying the margin of appreciation, came to the conclusion that A's deportation would not violate Article 2 or 3 of the ECHR. They decided that his conversion and political activism would not put him at a real risk of being persecuted on his return. As the ruling states:

\footnotetext{
${ }^{1}$ Doctoral Student, Teaching Assistant, University Paris I Panthéon-Sorbonne, 12 place du Panthéon, 75005 Paris. E-mail: deborah.thebault@hotmail.fr

2 Doctoral Candidate, Centre on Migration, Policy, and Society, Institute of Social and Cultural Anthropology, University of Oxford. Email: lena.rose@anthro.ox.ac.uk.
} 
They considered that his conversion to Christianity did not in and of itself expose him to a real risk of ill-treatment. Such a risk could exist if he proselytised or attracted public attention in another way. Based on his statement, they considered that he did not intend to practise his faith in such a manner. ${ }^{3}$

Their conclusion was based on the assumption that A would be able to keep his new-found faith quiet from those around him, including from the Iranian authorities (by not proselytising or attracting public attention). The Swiss asylum authorities even explicitly assumed that the Iranian authorities were aware of conversions to Christianity as asylum strategy, and therefore would be willing to 'overlook' the applicant's change of faith. ${ }^{4}$ This, of course, assumes that the conversion was not genuine in the first place, which - while not the basis of the decision had been an underlying assumption of the Swiss authorities:

They also doubted that the applicant's conversion was genuine and lasting, noting, in particular, that it had occurred after the applicant's first asylum application had been rejected, that the baptism had taken place in a house church rather than a church recognised by the State, and that the applicant did not base his conversion on the key aspects of Christianity, but on the personal relationships he had formed with members of his church community. ${ }^{5}$

Other asylum cases based on religious conversion base their doubt of the respective applicants' faith on similar reasons. For example, the TM and YA $v$ the Netherlands ${ }^{6}$ case dealt with two asylum applicants of Iranian nationality who had converted to Christianity. They got baptized in 2014 and based their application on the risk of persecution if they were deported to Iran. The national Dutch immigration authorities rejected the applicants' asylum applications for lack of credibility. The Deputy Minister first considered that "the applicant's baptism did not in itself constitute a fact that confirmed the sincerity of their conversion". 7 Moreover, the applicants were not able to answer questions about the meetings supposedly held with the priest for their conversions and could not strengthen their statements about their sur place activities. The Regional Court confirmed this appraisal of the facts stating that "it was relatively easy to join a church, study the Bible and get baptized, but that such circumstances could not be decisive". 8

Yet, a careful investigation of the reasoning of the Swiss authorities in the present case affirmed by the ECtHR - reveals that the decision-makers were operating on a number of assumptions about the applicant's Christianity and conversion. These may not be unique to this present case alone. It is important to consider these assumptions, because assumptions made by the decision makers affect both their assessment of the credibility of the applicant's conversion, as well as his future religious practice, thus greatly influencing their assessment of the risk he would face when deported back to Iran. We argue that the authorities based their decision on a culturally biased understanding of Christianity, which may have skewed the appreciation of the real risk the applicant will be subjected to on his return to Iran. Thus, in the following, we critically examine the authorities' appreciation of the claimant's faith and its consequences, before discussing the role of the ECtHR in the matter.

\footnotetext{
${ }^{3} A v$ Switzerland (App no 60342/16) ECHR 19 December 2017, § 14.

${ }^{4}$ A v Switzerland (App no 60342/16) ECHR 19 December 2017, § 20.

${ }^{5}$ A v Switzerland (App no 60342/16) ECHR 19 December 2017, § 14.

${ }^{6}$ TM and YA $v$ the Netherlands (App no 209/16) ECHR 5 July 2016.

${ }^{7}$ TM and YA v the Netherlands (App no 209/16) ECHR 5 July 2016, $\$ 11$.

${ }^{8}$ TM and YA $v$ the Netherlands (App no 209/16) ECHR 5 July 2016, §14.
} 
First of all, let us consider the assessment of the authenticity of the applicant's conversion. While this did not form the basis of the decision, the understanding of the applicant's faith by the asylum authorities has direct bearing on their understanding of the risk involved in his deportation. The genuineness of A's conversion to Christianity was doubted for three reasons: 1) he converted after his first asylum application had been rejected (thus suggesting he tried to use conversion as a strategy to achieve refugee status); 2) he was baptised in a house church rather than a state church; 3) his reasoning for being attracted to Christianity emphasised not the "key aspects" of Christianity, but the relationships with members of his church community.

There is no question that to assess the genuineness of what can be a deeply personal and internal act, such as a religious conversion, is notoriously difficult. The timing of A's conversion may of course indicate that it was - at least initially - an attempt to qualify for protection under section 83 of the Aliens Act of 16 December 2005. And yet, it seems that, like many conversion processes, his had started a good time before he used it as the basis for his second asylum claim: according to his answers during the trial in January 2014, he had already shown interest in a Catholic Church in 2011, and had started attending the church in which he was to be baptised already before his first asylum application was rejected in February 2013. Between the time of his baptism in August 2013 and the 2017 trial before the ECtHR, he had thus been a member of his church for approximately four years. Scholars of Christianity as well as expert reports on conversion suggest that religious conversion is a gradual process that may begin long before one even enters a church, and continue long after baptism. ${ }^{9}$ One can assume that, after at least four years of actively practising one's faith (the applicant has attended not just services at his church, but also up to two mid-week Bible discussions), it forms a significant part of one's identity.

Another reason for the asylum authorities' doubts as to the authenticity of the claimant's conversion was the fact that he was baptised in a privately run Pentecostal house church. Considering that only $4.4 \%$ of Switzerland's population counts as 'evangelical' (contrasted with $75.7 \%$ who would describe themselves as 'Christian') ${ }^{10}$, it is understandable that the asylum authorities harbour some doubt concerning the unusual institutional arrangement of house churches. Yet, while not frequent in Switzerland, Pentecostal Christianity ${ }^{11}$ is among the fastest growing and most wide-spread forms of Christianity worldwide ${ }^{12}$. Pentecostalism's emphasis on proselytising, Bible study, and personal growth and accountability as part of a Christian community are not at all uncommon ${ }^{13}$, and would explain the key aspects the claimant named when explaining his faith:

\footnotetext{
${ }^{9}$ Szabolcs Kéri \& Christina Sleiman, 'Religious Conversion to Christianity in Muslim Refugees in Europe' (2017) Archive for the Psychology of Religion, 39(3), 283-294, https://doi.org/10.1163/15736121-12341344. This is also stated in the follow-up version of the United Kingdom Home Office's Country Policy and Information Note referred to in the judgement, "Iran: Christians and Christian converts" (March 2018) p 20f.

10 According to the country profile of the Christian organisation, Operation World. http://www.operationworld.org/country/swit/owtext.html [accessed 12/07/2018]

${ }^{11}$ For the purpose of this comment, we consider Pentecostal Christianity as a form of evangelical Christianity. For a more detailed differentiation, see for example Coleman and Hackett (eds.). The anthropology of global pentecostalism and evangelicalism (NYU Press, 2015).

${ }_{12}$ Simon Coleman, \& Rosalind I. J. Hackett (eds.). The anthropology of global pentecostalism and evangelicalism (NYU Press, 2015); see also J. Robbins, The globalization of Pentecostal and Charismatic Christianity. Annual Review of Anthropology, 2004, 33, 117-143.

${ }^{13}$ James S. Bielo, Words upon the Word: an ethnography of evangelical group Bible study (NYU Press, 2009) ; Tanya M. Luhrmann, When God talks back: understanding the American evangelical relationship with God (Alfred A. Knopf, 2012).
} 
For him, being a Christian meant believing in Jesus Christ and spreading his message. He stated that he continued to study the Bible and recited parts of it. The principle of honesty enshrined in Christianity was particularly important to him. ${ }^{14}$

The applicant seems to be following a Pentecostal form of Christianity, which the asylum authorities may not have been familiar with. They seem to have expected a particular narrative of conversion based on 'rational' arguments concerning the 'key aspects' of Christianity (or what they considered to be the religion's 'key aspects'). However, as scholars of conversion to evangelical forms of Christianity have shown, narratives of conversion in fact more often focus on "exploration and celebration of the inner, unique self", emotional as well as cognitive events ${ }^{16}$. For the applicant to stress the notion of honesty, and later to ascertain that "he would always retain the truthfulness of his faith, which nobody could take away from him"17, thus is in fact in line with evangelical conversion narratives.

On the basis of these observations, it is necessary to return to the asylum authorities' statement that the applicant would not face a real risk of persecution in Iran if he practiced his faith "in such a manner". From the statements of the applicant about how he intended to live out his faith, though scarce, it is possible to surmise that he was planning to practice his faith in the manner he was taught in the Pentecostal church he belonged to. This includes "sharing the message" of Jesus Christ (proselytising), continuing to form relationships with other Christians so as to foster accountability and growth (e.g. in a house church), as well as staying true to his faith in "honesty". The Swiss authorities' understanding of Christianity seems to suggest that he can, however, be a Christian without practicing his faith in this way, and that he could hide his conversion from his family and the state.

'What is Christianity' is a long-standing debate in the Anthropology of Christianity, considering its many forms and expressions ${ }^{18}$. How then could the Swiss authorities be so sure as to what kind of Christianity was permissible and acceptable in the case of A - were they not rather showing a cultural bias towards a traditional Western form of Christianity, betraying Christianity's many different forms? And do not all forms of Christianity require equal measure of protection under the right to religious freedom?

If the conversion of the applicant was genuine - which was not the focus of the authorities' considerations, and was therefore not assessed in sufficient ways - and he intended to practice his faith in the way described above, it would be very difficult indeed for him to keep his faith a secret from those around him, including the Iranian state. As the United Kingdom Home Office's Country Policy and Information Note "Iran: Christians and Christian converts"19 of March 2018 states, there is substantial risk for Iranians who have converted abroad. For example, Iranian bureaucracy continues to treat converts as Muslims on their return - all official documents and applications ask about a person's religious belonging, and ID cards

\footnotetext{
${ }^{14}$ A v Switzerland (App no 60342/16) ECHR 19 December 2017, § 13.

15 Miranda Klaver, Johan Roeland, Peter Versteeg, Hijme Stoffels \& Renca van Mulligen. God changes people: modes of authentication in Evangelical conversion narratives, Journal of Contemporary Religion, 2017, 32(2), 241, DOI: 10.1080/13537903.2017.1298905.

${ }^{16}$ L. Darwish. "When your heart is touched, it's not a decision": A Narrative Analysis of Iranian Muslim Conversion to Christianity. Studies in Religion/Sciences Religieuses, 2018, 47(1), 45-77, 47, https://doi.org/10.1177/0008429817732327.

${ }_{17}$ A v Switzerland (App no 60342/16) ECHR 19 December 2017, § 13.

${ }^{18}$ For a good summary, see Jon Bialecki. 'Virtual Christianity in an age of nominalist Anthropology', 2012 Anthropological Theory, 12(3), 295-319. https://doi.org/10.1177/1463499612469586.

${ }^{19}$ A v Switzerland (App no 60342/16) ECHR 19 December 2017, $§ 29$. While we quote in the following from the updated CPIN (March 2018), the relevant information was equally available to the authorities through its earlier edition (February 2017).
} 
stating a person's religion are required for many everyday transactions such as purchases, marriage, education, etc. ${ }^{20}$ Moreover, family and neighbours would very quickly become aware of the applicant's change of religion when he stops attending the mosque or participating in other Muslim practices. This is especially a concern considering that the applicant's father seems to have connections with the secret service, which means that the applicant's conversion could quickly come to the attention of the authorities. Family members themselves might feel that the convert has shamed the family through his change of faith, which puts him at risk of persecution by his own family ${ }^{21}$.

Further, based on his faith practice, the applicant may well seek out a house church in Iran, which would put him under particular scrutiny by the Iranian government ${ }^{22}$. If he were to practice his faith as an evangelical Christian as outlined above, his faith would require him also to proselytise - which is also a common practice among new believers. Elam Ministries, an influential international Christian organisation operating in Iran, states that a person's Christian faith concerns all aspects of their life: converts in Iran "must be secret believers and are unable to speak of their faith to anyone else and to live an openly Christian lifestyle" 23 if they want to avoid persecution. This goes against the notion of honesty important to the applicant, as well as his right to live out and share his religion (Article 9 of the ECHR). If he did live out his faith in its particular form of Christianity, he would face a real risk of persecution in violation of Articles 2 and 3.

The Court considered in this case that the general human rights situation in Iran did not, per $s e$, prevent the deportation of any Iranian national. However, in this case the judgement may be based on an understanding of Christianity that is lacking in nuance and depth. The authorities prescribe a certain kind of Christianity which is not in accordance with the specific Christian tradition of the claimant. It would have been fairer to find ways to examine the authenticity of the applicant's conversion in more detail (taking into regard Christianity's many variants), rather than base the judgement on the consequences of the kind of Christianity the authorities assumed he was practicing.

\section{ECtHR and its Margin of Appreciation}

Further, it is noteworthy that in this present case, the ECtHR did not reconsider the national authorities' deliberations regarding the applicant's conversion to Christianity, or question the Swiss ruling, at all. This is in accordance with previous cases on religious conversions before the ECtHR, in particular regarding the argument of a public manifestation of the faith. The ECtHR gives a certain margin of appreciation to the different contracting States in the interpretation of the Convention, in particular Articles 2 and 3. However, this margin of appreciation fluctuates drastically when it comes to appreciating the conversion of an asylum applicant to Christianity before the European national authorities. Over the last decade, we can observe a growth of asylum applications of refugees converted to Christianity before the different European national authorities, and who based their asylum claims on this basis.

In the TM and YA $v$ The Netherlands ${ }^{24}$ case referred to above, for example, the Dutch authorities rejected the claim on the basis that baptism and going to church were not decisive in ascertaining the credibility of a conversion. In that case the ECtHR stated that "the national authorities are best placed to assess not just the facts but, more particularly, the credibility of

\footnotetext{
${ }^{20}$ Country Policy and Information Note, Iran: Christians and Christian converts, March 2018, p. 17.

${ }^{21}$ Country Policy and Information Note, Iran: Christians and Christian converts, March 2018, p. 24.

${ }^{22}$ Country Policy and Information Note, Iran: Christians and Christian converts, March 2018, p. $14 \mathrm{ff}$.

${ }^{23}$ Country Policy and Information Note, Iran: Christians and Christian converts, March 2018, p. 31, § 8.1.1.

${ }^{24}$ TM and YA $v$ the Netherlands (App no 209/16) ECHR 5 July 2016.
} 
witnesses since it is they who have had an opportunity to see, hear and assess the demeanour of the individual concerned"25. It appears that the lack of belief of the Dutch authorities in the applicants' asylum statements was based on the "vague, contradictory and cursory" statements by the applicant regarding their conversion. As in the case of $A v$ Switzerland, the ECtHR did not reconsider the consideration by the national authorities of the credibility of the applicant's conversion. That consideration was based on the national authorities' own particular understanding of religious practice.

In earlier precedents, the ECtHR gave a narrower margin of appreciation to the states. For example, in Metropolitan Church of Bessarabia and Others $v$ Moldova $^{26}$, the Court stated that the manifestation of religion could not be separated from faith and was an essential component of freedom of religion, no matter how it was practiced, in public or in private ${ }^{27}$.

Similarly within the European Union, the Court of Justice of the European Union considered the point in Bundesrepublik Deutschland $v Y Z^{28}$. The applicants were members of an Islamic reformist movement and had been ill-treated by some home village groups in Pakistan. They requested asylum in Germany. The German national authorities considered, after a thorough examination of the case, that "the public practice of their faith is essential in order for them to preserve their religious identity" 29 . According to the opinion of Advocate General Bot delivered in this case, the legal term 'in private or in public' "should not be interpreted as being mutually exclusive or as leaving a choice to the public authorities"

It is interesting to compare the more recent assessments within the European Convention on Human Rights framework with the EU legislation and particularly with Article 10 of Directive 2004/83/EC ${ }^{31}$ which sits within the European Union framework. This provides the elements required to be taken into account by member states of the European Union when considering the risk of religious persecution. Article 10(1)(b) defines the "concept" of religion as including "theistic, non-theistic and atheistic beliefs, the participation in, or abstention from, formal worship in private or in public, either alone or in community with others, other religious acts or expressions of view, or forms of personal or communal conduct based on or mandated by any religious belief'. This article does not establish any difference of interpretation based on the private or public nature of the religious practice or the manifestation of the faith. It is suggested that the European Court of human rights? would do well to consider the concept of "religion" applied within the European Union, albeit that this consists of a smaller group of states than those comprised within the European Convention of Human Rights. This is particularly so first, since these states have built expertise into the formulation of the definitions within the Directive. Second, since the EU states are also highly influential within the ECHR framework. It is proposed that national authorities within the ECHR should adopt the same understanding of religion as that adopted in article 10(1)(b) of Directive 2004/83/EC and should not distinguish between the public practice of religion and the practice in private circles in order to justify rejecting asylum applications. Similarly, the ECtHR should not accept national rulings on this basis.

\footnotetext{
${ }^{25}$ TM and YA v the Netherlands (App no 209/16) ECHR 5 July 2016, §23.

${ }^{26}$ Metropolitan Church of Bessarabia and Others $v$ Moldova (App no 45701/99) ECHR 13 December 2001.

${ }^{27}$ Metropolitan Church of Bessarabia and Others $v$ Moldova (App no 45701/99) ECHR 13 December 2001 $\S 114$.

${ }^{28}$ Bundesrepublik Deutschland $v$ Y Z (C-71/11 \& C-99-11) CJEU 5 September 2012.

${ }^{29}$ Bundesrepublik Deutschland v Y Z (C-71/11 \& C-99-11) CJEU 5 September 2012 § 40.

${ }^{30}$ Bundesrepublik Deutschland v Y Z (C-71/11 \& C-99-11) CJEU 5 September 2012, opinion of Advocate General Bot delivered on 19 April 2012 ECLI:EU:C:2012:224, 50.

${ }^{31}$ Council Directive 2004/83/EC of 29 April 2004 on minimum standards for the qualification and status of third country nationals or stateless persons as refugees or as persons who otherwise need international protection and the content of the protection granted.
} 


\section{Conclusion}

According to the opinion of Advocate General Bot in the Bundesrepublik Deutschland v Y Z case, the protection granted to asylum seekers is "to restrict the recognition of refugee status to individuals who may be exposed to a serious denial or systemic infringement of their most fundamental rights, and whose life has become intolerable in their country of origin" 32 . We have argued that the appreciation and interpretation of the credibility of someone's faith coupled with the judgment as to whether that faith necessitates public expression creates a risk of arbitrariness within the ECHR framework. This is particularly so as a result of the application by the ECtHR of the margin of appreciation given to the States. Thus there is a failure to recognise the risk of a serious denial or systematic infringement of an individuals' fundamental rights.

Word count (excl Bibliography, including full footnotes (need edits)): 3,940

\section{Bibliography}

Bialecki, J. (2012). Virtual Christianity in an age of nominalist Anthropology. Anthropological Theory, 12(3), 295-319. https://doi.org/10.1177/1463499612469586

Bielo, J. S. (2009). Words upon the Word: an ethnography of evangelical group Bible study. New York: New York University Press.

Coleman, S., \& Hackett, R. I. J. (Eds.). (2015). The anthropology of global pentecostalism and evangelicalism. NewYork: NYU Press.

Darwish, L. (2018). "When your heart is touched, it's not a decision": A Narrative Analysis of Iranian Muslim Conversion to Christianity. Studies in Religion/Sciences Religieuses, 47(1), 45-77. https://doi.org/10.1177/0008429817732327

Home Office. (2018). Country Policy and Information Note Iran: Christians and Christian converts, Version 4.0

Kéri, S., \& Sleiman, C. (2017). Religious Conversion to Christianity in Muslim Refugees in Europe. Archive for the Psychology of Religion, 39(3), 283-294. https://doi.org/10.1163/15736121-12341344

Klaver, M. (2011). From Sprinkling to Immersion: Conversion and Baptism in Dutch Evangelicalism. Ethnos, 76(4), 469-488. https://doi.org/10.1080/00141844.2011.590216

Luhrmann, T. M. (2012). When God talks back: understanding the American evangelical relationship with God. New York: Alfred A. Knopf.

Robbins, J. (2004). The globalization of Pentecostal and Charismatic Christianity. Annual Review of Anthropology, 33, 117-143.

\footnotetext{
32 Bundesrepublik Deutschland v Y Z (C-71/11 \& C-99-11) CJEU 5 September 2012, opinion of Advocate General Bot delivered on 19 April 2012 ECLI:EU:C:2012:224, 28.
} 
